\title{
Diagnose Disease Expert System Respiratory Tract Infection Method Using Certainty Factor
}

\author{
Aritana Lahagu ${ }^{1}$, Erwin Panggabean ${ }^{2}$ \\ 1.2 Informatics Engineering Study Program, STMIK Pelita Nusantara Medan, Jl. Iskandar \\ Muda 1 Medan, North Sumatra 20154, Indonesia

\begin{abstract}
Respiratory tract infections are infectious diseases that interfere with the process of human breathing. When the breathing process takes place, there are often various kinds of diseases, most of which can only be treated by a lung specialist. The arrival of a pulmonary specialist for consultation can take hours and is expensive. Then we need an expert system that can quickly find out the type of disease in human breathing and how to handle it and the solutions that will be provided. Expert system is a system that uses human knowledge to find out the system that is entered into a computer and then is used to solve problems that usually require expertise or human expertise. One application of an expert system to diagnose respiratory tract infections is to use the certainty factor method. The certainty factor method is a method used to solve problems from uncertain answers, and also produce uncertain answers. This uncertainty is influenced by two factors, namely uncertain rules and uncertain user answers. The research aims to build an expert system application for handling respiratory tract infection problems with Visual Studio 2010 as a tool for designing applications and using Microsoft Access 2007 Database as a database. This expert system is able to calculate similarity in weight calculation based on symptoms of respiratory tract infection using certainty factor methods and provide reports using crystal reports.
\end{abstract}

Keywords: Respiratory tract infections, expert systems, certainty factor methods.

\section{Introduction}

ISPA or pernapasanmerupakan tract infections, infections that interfere with human respiratory process. In general, the infection is caused by a virus that attacks the trachea (breathing tube), the nose, even the lungs. In this study the author discusses Disease pernapasankarena respiratory tract infection is a window that can assist and detect abnormalities or other diseases in the human body in because of problems that arise in Breathing can reflect the health condition of the human body. Therefore, it is better to recognize the symptoms and signs of illness through disease caused by respiratory tract infections in humans.

Therefore, for no fault to make diagnosis in humans, the authors make the application of expert systems to diagnose diseases of respiratory tract infections to simplify and to determine disease dideritaoleh manusia.oleh therefore order not too late to get treatment, because a doctor or specialists have limited time for consultation to the patient, to the authors build an expert system for diagnosing respiratory infections by using certainty factor that may help resolve the issue. Methods certainty factor (CF) is a method that can define the size of certainty and uncertainty of a fact or a rule set.

This research will be designed an expert system to detect the type of disease Ispa. Due to the existence of this system, the public can find out in detail the symptoms of disease in the human respiratory infection and ways to overcome them before consulting a doctor. The system is designed based expert system using the method of Certainty Factordengan uses Visual Studio 2010, and data storage used is using Microsoft Access 2007. The end result of this application form types of illness based on the symptoms that have been selected. With the Ispa disease diagnosis expert system is expected to know in detail the symptoms of disease in humans Ispa and how to overcome them.

\section{Theory}

\section{a. Expert system}

The expert system is an artificial intelligence program that combines the knowledge base to base inference system to mimic an expert. The expert system is a system that tried to adopt human knowledge into a computer so that the computer can resolve the issue as was done by experts. It is expected that with this expert system, users can solve specific problems, without the help of experts in the field. An expert system is a computer system that sow (emulates) the ability of decision-making from an expert. Emulatesberarti term expert system is expected to work in all respects like an expert. An emulation is much more powerful than a simulation only takes something that is evident in several fields or things. Part of the expert system is comprised of two main components which contain baseyang knowledge Knowledge and Inference engine that draws conclusions. The conclusion of the expert system is in response to user requests. [1] 


\section{b. certainty Factor}

Factor MetodeCertainty proposed by Shortliffe in 1975 to mengkomodasikan uncertainty of thought (inexact reasoning) an expert. An expert such as a doctor often analyze the existing information with the phrase "may", "likely", "almost certainly". To mengkomodasikan it uses Certainty Factor (CF) in order to describe the level of confidence of experts on the matter at hand.

In expressing degrees of certainty, certainty factoruntuk mengansumsikan degree of certainty an expert to the data. This concept was formulated in the following basic formula:

- $\quad \mathrm{CF}[\mathrm{H}, \mathrm{E}]=\mathrm{MB}[\mathrm{H}, \mathrm{E}]-\mathrm{MD}[\mathrm{H}, \mathrm{E}]$

- $\quad \operatorname{MB}(h, \mathrm{e} 1 \wedge \mathrm{e} 2)=\mathrm{MB}[\mathrm{h}, \mathrm{e} 1]+\mathrm{MB}[\mathrm{h}, \mathrm{e} 2] *(1-\mathrm{MB}[\mathrm{h}, \mathrm{e} 1])$

- $\operatorname{MD}(\mathrm{h}, \mathrm{e} 1 \wedge \mathrm{e} 2)=\mathrm{MD}[\mathrm{h}, \mathrm{e} 1]+\mathrm{MD}[\mathrm{h}, \mathrm{e} 2] *(1-\mathrm{MD}[\mathrm{h}, \mathrm{e} 1])$

The next calculation is a combination of two or lebihrule with different tetapidalam evidence of the same hypothesis.

- Rule $1 \mathrm{CF}(\mathrm{h}, \mathrm{e} 1)=\mathrm{CF} 1=\mathrm{C}(\mathrm{e} 1) \times \mathrm{CF}$ Rule1)

- Rule 2 CF (h, e2) = CF2 = C (e2) x CF Rule2)

- CFcombinasi $[\mathrm{CF} 1, \mathrm{CF} 2]=\mathrm{CF} 1+\mathrm{CF} 2$ (1-CF1).

To calculate the percentage of the disease, then use the equation:

- Cfpersentase $=$ Cfkombinasi $* 100 \%$

Information:

- $\quad \mathrm{CF}=$ Certainty

- $\mathrm{MB}=$ meansure of believe.

- $\quad \mathrm{MD}=$ meansure of disbelieve.

- $\mathrm{H}=$ hypothesis (alleged)

- $\mathrm{E}=$ Evidence (events / facts)

TABLE 1

VALUES CERTAINTY FACTOR

\begin{tabular}{ccc}
\hline Certainty factor & MB & MD \\
\hline Not sure & $0-0.2$ & $0-0.2$ \\
bit unsure & $0.3-0.4$ & $0.3-0.4$ \\
sure enough & $0.5-0.6$ & $0.5-0.6$ \\
Sure & $0.7-0.8$ & $0.7-0.8$ \\
Very sure & 0.9 to 1 & 0.9 to 1
\end{tabular}

\section{c. Ispa disease}

ISPA or respiratory tract infection is an infection that interfere with breathing humans in performing daily activities. In general, these infections are caused by a virus that attacks the trachea (breathing tube), lungs, and even countISPA The term is derived from three elements namely the infection, respiratory tract, where understanding as follows:

a. InfeksiAdalah an incoming germs or microorganisms into the human body and multiply, causing the symptoms of respiratory tract infections.

b. Respiratory tract is an organ from the nose to the alveoli along adneksanya organs such as the sinuses, middle ear and pleural cavity.

\section{Analysis}

a. table Disease

The following is a table of Diseases of the respiratory tract infections as well as solutions that can be done to overcome the attacks of respiratory tract infeki respectively. [2]

Table 2

table illness

\begin{tabular}{ll}
\hline Code & Ispa Disease Type \\
\hline P01 & Pharyngitis \\
P02 & Asthma \\
P03 & tbc \\
P04 & rhinitis \\
P05 & Bronchitis \\
P06 & pneumonia \\
P07 & nasopharyngitis \\
\hline
\end{tabular}

b. Table Symptoms

On the table there are symptoms of the value of the MB, MD of symptom data. MB value is the value of the trust an expert, and the value MD is an expert on the value distrust diberiukan disease symptoms. 
Table 3

table symptoms

\begin{tabular}{ll}
\hline $\begin{array}{c}\text { Symptoms } \\
\text { code }\end{array}$ & \multicolumn{1}{c}{ Symptoms name } \\
\hline G01 & Sneezing \\
\hline G02 & Headache \\
\hline G03 & Cough \\
\hline G04 & sore sore \\
\hline G05 & shiver \\
\hline G06 & Bedebar heart Debar \\
\hline G07 & difficulty speaking \\
\hline G08 & Terihat lips turned blue \\
\hline G09 & Seemed weak and listless \\
\hline G10 & face Pucak \\
\hline G11 & Fever \\
\hline G12 & Loss of appetite \\
\hline G13 & Urine that change color \\
\hline G14 & runny nose \\
\hline G15 & Itchy eyes \\
\hline G16 & Fatigue \\
\hline G17 & Cough accompanied by phlegm yellow \\
\hline G18 & sore throat \\
\hline G19 & Hard to breathe \\
\hline G20 & Nausea or vomiting \\
\hline G21 & There genjolan in the nose or throat \\
\hline G22 & Pain in the ear \\
\hline G23 & Blurred vision or double \\
\hline &
\end{tabular}

c. Table Rule (Rule)

Table 4

table Rules

\begin{tabular}{|c|c|c|c|}
\hline & & & \\
\hline & & & \\
\hline \multirow{5}{*}{ Pharyngitis } & Sneezing & 0.8 & $0: 02$ \\
\hline & Headache & 0.7 & $0: 04$ \\
\hline & Cough & 0.6 & $0: 08$ \\
\hline & Aches & 0.9 & 0:01 \\
\hline & shiver & 0.8 & $0: 02$ \\
\hline \multirow{5}{*}{ Asthma } & $\begin{array}{l}\text { Heart pounding } \\
\text { pounding }\end{array}$ & 0.8 & $0: 01$ \\
\hline & difficulty speaking & 0.8 & $0: 03$ \\
\hline & Lips look bluish & 0.9 & 0:02 \\
\hline & heart berdebar2 & 0.85 & $0: 04$ \\
\hline & Pale face & 0.8 & 0:03 \\
\hline \multirow{4}{*}{$\mathrm{TBC}$} & Cough & 0.5 & $0: 02$ \\
\hline & Fever & 0.8 & 0:03 \\
\hline & Loss of appetite & 0.9 & 0:02 \\
\hline & Urine Changing Colors & 0.8 & $0: 02$ \\
\hline \multirow{3}{*}{ rhinitis } & runny nose & 0.85 & $0: 05$ \\
\hline & Itchy eyes & 0.9 & 0:03 \\
\hline & Fatigue. & 0.8 & 0:02 \\
\hline \multirow{4}{*}{ Bronchitis } & $\begin{array}{l}\text { Cough with yellow } \\
\text { mucus }\end{array}$ & 0.8 & $0: 01$ \\
\hline & Sore throat & 0.8 & $0: 03$ \\
\hline & Hard to breathe & 0.9 & $0: 02$ \\
\hline & Runny or stuffy nose & 0.8 & $0: 01$ \\
\hline \multirow[b]{3}{*}{ Pneumonia } & Sweating and shivering & 0.7 & 0:03 \\
\hline & Hard to breathe & 0.7 & 0:01 \\
\hline & Nauseaor vomiting & 0.95 & $0: 05$ \\
\hline \multirow{3}{*}{ nasopharyngit } & $\begin{array}{l}\text { There bump in the nose } \\
\text { or neck }\end{array}$ & 0.95 & $0: 02$ \\
\hline & Sore throat & 0.9 & $0: 02$ \\
\hline & $\begin{array}{l}\text { Ear pain or ringing in the } \\
\text { ears }\end{array}$ & 0.95 & $0: 02$ \\
\hline
\end{tabular}

